\title{
An Assessment of Impact of GST on India's Online Retail Sector
}

\author{
S. Kumar ${ }^{1}$, V.K. Tyagi ${ }^{2}$, and T. Vashishat ${ }^{3 *}$
}

${ }^{1 \& 2}$ Department of Marketing and Supply Chain Management, School of Business \& Management Studies, Central University of Himachal Pradesh, TAB 2 Dharamshala, Kangra, Himachal Pradesh, India

${ }^{3}$ Department of Tourism and Travel Management, School of Tourism, Travel and Hospitality Management, Central University of Himachal Pradesh, TAB 2 Dharamshala, Kangra, Himachal Pradesh, India

*Corresponding author: tarun.vashishat@gmail.com

\begin{abstract}
The online retail market in India is relatively new and still adapting to the global business environment. Also, conventional tax regime was neither able to cover all e-commerce transactions nor give it a proper space to flourish. The launch of Goods and Services Tax (GST) changed the taxation scenario in India from a very complex tax structure comprising of around 500 different kinds of taxes to a simpler tax regime with just 3 broad tax categories while having both positive and negative impacts on industries operating in organized and unorganized manner. The objective of this exploratory, qualitative, and non-empirical paper is to explore and present the consequences of the introduction of GST on the Indian Economy with special reference to the online retail industry in India. Researchers reviewed the reports of various departments of Government of India (such as the Central Board of Excise and Customs); the GST Council reports up to $30^{\text {th }}$ meeting held on September $28^{\text {th }}$ 2018; Honorable Finance Minister's speech on GST; and interviews of government officials. This paper may provide useful insights to the online retailers, suppliers and most importantly, the common buyers in understanding the changes brought by GST and help the GST Council in making further amendments in the Act.
\end{abstract}

Keywords: GST, Indirect Tax, Online Retail, VAT, Indian Economy

After 17 years of its conceptualization (Subramanian, 2015), on June 30, 2017, Indian Prime Minister Narendra Modi launched the much anticipated Goods and Services Tax (GST) reform for making the country one unified common market with the proposed objectives of increasing revenue collection, enhancing of tax base, checking the tax evasion and bringing uniformity in the indirect taxation (Saurav, 2018). GST is being considered as the most significant indirect tax reform since independence, and the most significant economic reform after the LPG (Liberalization, Privatization and Globalization) model implementation of 1991 (TOI, 2017), having both macroeconomic and microeconomic effects on the Indian economy. In the pre-GST era, India had one of the most complex tax structures globally which needed to be changed (Agarwal, 2017). The tax used to be collected at each phase by the centre and the state governments separately, at several different rates, on the full value of the goods. (Arora, et al., 2017). But things have now changed with the introduction of GST, which is a unified indirect tax levied across the nation on both products and services, treated at par.

GST is a value-added tax; where one pays tax on their output and gets a rebate on the tax which one paid for their input. Under GST, a person pays tax on the value added at each stage and no additional tax on tax has to be paid, thereby cancelling the chances of cascading of taxes. The rules and regulations governing GST were formulated by a dedicated GST Council (GST Council, 2017) which was created in September 2016 under article 279-A of the constitution of India and has members of all major political parties. On the recommendations of 
the Council- Central GST (CGST) bill, Integrated GST (IGST) bill, Union territory GST (UTGST) bill, and GST (Compensation to States) bill were passed in the Upper House of the Parliament on March 29, 2017 and by the Lower House of the parliament on April 06, 2017. Thus, GST came into force on July 1, 2017. In totality, three types of GSTs have been implemented in India. For inter-state transactions, the centre would collect the Integrated GST (IGST). The IGST would proposedly be equal to CGST plus SGST. For intra-state transactions, the tax will have two components, i.e., Central GST (CGST), and State GST (SGST) being charged on the value of both goods and services. Both the Centre and States will concurrently charge GST through the value chain in the currently implemented system (Arora, et al. 2017).

GST got mixed reviews in India, as well as abroad. The move was a welcome step with a majority of people favouring it, however, there was also discontent with regards to the preparedness of the government and the fact that businesses were still not ready for its implementation (Tharoor, 2017). According to Amit Mitra, the Finance minister of West Bengal, preparations for GST were lacking and while he supported the idea of GST but also advised to delay it by a month as it required certain changes and neither GST Network (GSTN) nor the businesses were yet ready for it (PTI, 2017). As informed by the GSTN Chief Navin Kumar, the software was not even ready till $1^{\text {st }}$ July 2017; it was expected to be ready on $15^{\text {th }}$ July 2017 that too only the GSTR 1 (Seth, 2017). As a result, GST had to face protests all over India by business bodies including the Surat textile merchants, Ahmedabad cloth market (Press Trust of India, 2015), Tamil Nadu movie theatres (Madhav, 2017), Delhi cloth merchants (IANS, 2017). On the contrary, Chanda Kochhar, Managing Director, ICICI Bank called it, "a transformational structural reform with multiple benefits - greater productivity \& efficiency; enhanced ease of doing business; and improved tax compliance" (ANI, 2017). The United States, State Department spokesperson Elizabeth Trudeau suggested that the move would bring great benefits for the Indian economy and will expand trade and investment partnership between USA and India as (PTI, 2016).

In spite of all the praises and criticisms, the government went ahead with its implementation and tried to incorporate all corrective measures possible to reduce the potential adverse impacts. It sought to keep the revenue rate neutral so that in principle, the prices or taxes don't go up and average prices remain constant (GoI, 2015) (Subramanian, 2015). Anti-profitability clause was also implemented by the government whereby any company benefiting due to the tax rate changes has to pass it on to the consumers. It also helped in avoiding inflation which was observed in advanced countries just after the GST was implemented over there (Rastogi, 2017). Third party tax return preparers were appointed to help small and medium enterprises in registration and filing returns. The workshops were organized in both English and Hindi (Business Standard, 2017). A provision of deferred tax payment was also introduced (Subramanian, 2017). For the protection of the states from losses caused due to GST, another provision was introduced as per which any loss to the state for next five years will be compensated by the central government as per The Goods and Services Tax (Compensation to States) Act (CBEC Goods and Service Tax, 2017). After the implementation of GST, regular meetings of the GST council have been organized in order to improvise the new taxation regime and make it even more effective for the overall economy. But transitional issues do follow whenever a reform like this is introduced which have to be removed gradually. GST also introduces an optional scheme, i.e., a 'composition scheme', which allows small businesses with a turnover of less than one and a half crore to pay lower taxes. This will relieve newly established businesses from the tax burden. Earlier, as per the Value Added Tax (VAT) structure, businesses with a turnover of more than ₹ Five lakh had to get VAT registration. Under GST this limit for mandatory registration has been raised to ₹ 20 lakhs, leading to the scope of growth for founders of many startups and small businesses (Kashyap, 2017).

Around 160 countries have GST or similar tax model (Singh, 2017) (Biswas, 2016). None of those countries has these many different tax slabs as there are in India (as shown in Table 1 and Table 2). In Brazil, center and state separately decides their rates whereas in Australia rates are decided only by the center (Subramanian, 2017), in India both 
Table 1: Details of Tax rates under GST

\begin{tabular}{ll}
\hline Percentage & Goods \\
\hline $0 \%$ & Printed books; Handloom; Sanitary Napkins \\
$0.25 \%$ & Rough precious; Semi-precious stones \\
$3 \%$ & Gold \\
$5 \%$ & Apparel below ₹ 1,000; Footwear below ₹ 500 \\
$12 \%$ & Apparel above ₹ 1,000; Kitchenware; Condensed milk; Diabetic food; Handbags; Glassware; Art ware \\
$18 \%$ & Biscuits; Pasta; Steel Products; Furniture; Bags and Suitcases; Beauty products; Television \\
$28 \%$ & Aerated Water; Paan Masala, Cigarettes \\
$28 \%+$ cess & Luxury Vehicle, Large Cars. \\
\hline
\end{tabular}

Source: Economic Times, 2017; Central Board of Excise and Custom, 2017.

Table 2: Details of Tax rates in different nations

\begin{tabular}{lll}
\hline Country & Rate of Tax & Year of implementation \\
\hline France & $2.1 \%, 5.5 \%, 10 \%, 20 \%$ & 1954 (first country) \\
New Zealand & Started with 10\% increased to 15\% in 2010 & 1986 \\
Australia & $10 \%$, now planning to increase it to 15\% & 2000 \\
Singapore & Started with 3\% and increased to 7\% in 2007 & 1994 \\
Malaysia & $6 \%$ & 2015 \\
Canada & $5 \%$ & 1991 \\
\hline
\end{tabular}

Source: Arora, et al. 2017.

state and center mutually decided the rates. So, many exemptions and multiple rates can make the tax system less effective (Cnossen, 2013). However different rates could be the right decision in such a demographically diverse nation like India. A single rate would not be advisable nor possible here. Luxury car and baby milk cannot and should not be charged the same tax. Indian GST rates are higher than other nations, but the high rate on few items compensates the products of necessity in zero tax rate slab. Although many economists believed a single middle tax rate would have been better, the actual results will be known only in the longer run. Goods which are kept outside GST are Alcohol, Tobacco, Entertainment tax, Real estate, electricity, petrol, and Diesel; which are still under the control of state governments. However, Both the Centre and the States should try to include everything under GST, which implies that petroleum products, electricity, alcohol, the immovable property should all be in the GST base (Cnossen, 2013); to make it more effective and efficient. Alcohol will not come under GST as per The Constitution of India, rest all depends upon the GST Council to decide, Petroleum will come under GST after 5 years (Economic Times, 2017); (Subramanian, 2015).

In addition, with multiple tax rates, India also has the highest rate of $28 \%$ with a bracket of $40 \%$ as peak rate, ceiling rate (Central Board of Excise and Custom, 2017). Moreover, mainly in all the countries which implemented GST or an equivalent tax, the rate was increased after years of implementation. So, India having a little higher initial rate could be the right decision.

According to the Section 43B(d) of the Model GST Law, 'electronic commerce' means the supply of goods or services including digital products over digital or electronic network; and 'electronic commerce operator' means any person who owns, operates or manages a digital or electronic platform for electronic commerce (GST Council, 2016, p. 15). GST registrations for entities mandated to collect tax at source, i.e., e-commerce operators were started from September 18. And e-commerce companies were required to collect one per cent TCS while making payment to suppliers under GST, which was proposed on July 1, 2017. Following industry demands, the government in June decided to defer 
the TCS provision for a smooth rollout of GST but later started it from September 2017, although dates for collection of TCS were not finalized till November 2017 (Press Trust of India, 2017). But later implemented from October 1,2018 , from $28^{\text {th }}$ GST Council meeting held on July 21, 2018 (GST Council, 2018).

In the present research paper, researchers primarily focus on the perceived impacts of GST on electronic commerce, specifically online retail industry. The paper discusses both positive and negative perceived impacts of GST with respect to the online retail sector and concludes with policy recommendations, limitations and future scope of research.

\section{RESULTS AND DISCUSSION}

With the advent of GST, it would be easier for companies to comply with documentation and regulations in different states, which will help the new businesses in their formation. It will also help formalization of the businesses and increased investments in organized sectors, which is perfect for the startups and e-commerce firms are mainly the startups (Subramanian, 2015), as most of them are recently formed. Hence it will help entrepreneurs in starting and managing new businesses.

In the pre-GST regime, there was no uniformity in the tax rates among the different states, and therefore every state used to determine its own tax rates specific to the products. For example, a product in state $\mathrm{A}$ is taxed under VAT at five per cent and in state B at 14.50 per cent. As a result, the sellers in state B would not want to sell locally but would prefer to sell in state A, resulting in the loss of revenue for the state. Earlier, prior to GST implementation, Karnataka had a tax rate of $5 \%$ on Mobile Phone, whereas, Maharashtra charged $13.5 \%$ for the same. Post-GST, there are standard tax rates for each product bringing online retailers and physical retailers to the common grounds in terms of costing and pricing (ET Retail, 2017). With the arrival of GST, good or service supplied by a state to any other state the tax would be same, which would simplify the system. Earlier every state had entry tax which now will be removed, making the movement of goods smoother, simpler and cheaper (Subramanian, 2015). This will also reduce the corruption at state entries.
Logistics and warehousing are something on which any e-commerce company relies the most; their business is not run through physical stores but through the Logistics, which is its lifeline. Due to GST interstate transfer of goods will become easier. In the past, if a good was moved from Mumbai to Delhi, it used to get stopped at several different places for octroy; leading to $20 \%$ delay in logistics, hence increasing logistics costs by $20 \%$ (Subramanian, 2015). Due to the arrival of GST transportation/logistics on which the e-commerce depends the most will become cheaper and smoother. With the starting of e-way billing in interstate transactions from April 01, 2018 and on intrastate supplies from June 16, 2018, things got more smoothened up. There is also relaxation for the bills amounting up to ₹ 50,000, which will make things easier for online suppliers and small businesses (Seth, 2018).

In past the cost of logistics was very high in India, costing about 15 per cent of GDP. In developed markets, it stands at about 8 per cent. Time and cost incurred for crossing borders in India were 6-7 times than other countries (Subramanian, 2015). With GST, multiple layers of tax will get reduced thus bringing down the overall cost. In the long-term, it can also contribute to reducing the unorganized element in the logistics sector. Also, with state-level taxes being incorporated under GST, e-commerce platforms can reduce costs on warehousing as they will not require maintaining huge warehouses across different states. Such warehouses were earlier generally operating below their capacities, leading to inefficiencies and increased costs for storage. Now, e-commerce marketplaces can opt for maintaining lesser warehouses at some strategic locations. These strategically maintained logistics hubs will attract Foreign Direct Investment (FDI) inflows and lead to increased efficiency. With the free movement across the states, e-commerce sellers will be free to transport to any location in India.

Initially, transport Agencies was not willing to provide services to the unregistered firms. In order to resolve the issue faced by small unregistered businesses, the services provided by a Transport Agency to unregistered firms were made exempt from GST in $22^{\text {nd }}$ meeting of GST Council on 6th October 2017 (GST Council, 2016); which is a welcome move for the protection of the SMEs and 
unorganized suppliers, who are the major suppliers in online retailing.

Under GST, goods and services will get the same treatment (Dash, 2017) (Subramanian, 2015), which will decrease complexity and increase uniformity, leading to increase in the ease of doing business. Decrease in Tax-related trade barriers, Red-tapism, and leakages (Arora, et al. 2017) will increase the coherence and smoothening of the system. In addition to that, the best thing brought by GST is that based on different parameters; each company will get compliance rating which will be displayed on the GST Network (GSTN). It will help buyers in finding a suitable supplier/trader, after checking its rating. The rating will be done on the basis of punctuality in filing returns, payment of taxs, and transactional behavior of them (Shivashankar, 2017). This could be the most positive impact of GST on the e-commerce as they have to rely on small suppliers geographically so distinct that makes it difficult for inspections, but now a particular rating will help the operators in the selection of the vendors. Being a destination based tax it will allow exports to be done at zero taxes and imports taxed same as that of the domestic products, it will make the control over import/export easier (TOI, 2017).

The most selling segment online, i.e., books are still exempted from GST, which is quite a news for the online retailers (Central Board of Excise and Custom, 2017). GST may not even have a major effect on inflation due to anti profiting clause, where any company who is benefiting due to the tax rate changes has to pass it on to the consumers. (Indian Express Web Desk, 2017) Moreover on October 6, 2017; in 22nd GST Council Meeting; GST rates of 27 commodities were slashed down including on Ayurvedic medicines, scrap, etc. leading to still more reduction in prices. And in their $23^{\text {rd }}$ GST Council meeting the council brought down the list of products with $28 \%$ tax rate from 228 items to just 50 items; and also slashed the tax rates of many commodities with other rates, in the attempt to still reduce the prices (23rd GST Council Meeting, 2017). By July 2018 there were only 35 goods under the highest tax bracket (Press Trust of India, 2018). Further great news for online retail came in the $28^{\text {th }}$ GST Council meet where GST on the supply of e-books was reduced from $18 \%$ to $5 \%$ under green initiative (28th GST Council, 2018). In 29 $9^{\text {th }}$ GST
Council meeting held on August 04, 2018 Council suggested states to volunteer for providing cashback of $20 \%$ on GST component to the customers (limited to ₹ 100 per transaction) when payment is done through Rupay Debit Card, Bhim UPI, UPI Aadhar, USSD (Unstructured Supplementary Service Data) promoting consumers to go for online transactions (Cleartax, 2018).

Prior to GST, the major problem with the online retail was if someone bought something through e-commerce then the taxes were not collected in the state where goods were delivered. Only the state from where goods were supplied used to collect the tax, which the buying state or the state at the receiving end didn't like as they didn't get any tax benefit and therefore they used to put restrictions like entry tax, i.e., Octroi; now this problem will be solved as IGST will be collected by the centre in interstate transfer and will distribute with states accordingly (Central Board of Excise \& Customs, 2017).

As per the Indian Constitution there is freedom of trade and commerce throughout India (according to Article 301), but the old system of indirect taxation at the central and state levels was a serious obstacle towards building of a single common market in which businesses source, manufacture, and sell anywhere (Thirteenth Finance Commission, 2009) Pre GST our tax system promoted import from another country rather than producing domestically, GST will promote Make in India initiative (Subramanian, 2015). GST will promote Make in India, by making one common India: Person can source from one state or another; the rates would remain same (Subramanian, 2015). It will help in the reduction of confusion and bringing uniformity in return making India more competitive over imports and will boost India's growth rate.

GST has a major clause for invoice matching between purchase invoice and sales invoice that will increase tax compliance leading to the increase of organized businesses. It just can have one drawback that large companies may not be willing to work with small vendors who face problem in filing tax or who are not registered, but otherwise, it will have significant positive impacts. If A purchase from B, $B$ will report what it sold to $A$ and $A$ will report what it purchased from B; software will match it. If the seller is not paying tax, the buyer will not get 
its credit and will have to pay for the both. Hence the buyer will force the seller to file tax, or else will not do business with it in future. By this, chances of misreporting will reduce and chances of tax evaders getting caught will increase. And around 3 billion invoices will be matched every month (Nair, 2017). Post GST, it will be impossible to do business without GST Registration. Tax compliance or tax base would increase and hence reduce black money, tax evasion and corruption (Subramanian, 2015). Prices should come down as tax rates have come down due to which compliance should increase by at least $10 \%$, and in total, the revenue will remain constant, leaving no extra burden on the consumers (Subramanian, 2017). The government believes that by this move the revenue to the government will increase in spite of reduced tax rates due to increase in tax compliance, which will help in reduction of rates later (Subramanian, 2015).

GST is a kind of destination based value added tax (TOI, 2017), with a tax on the value, added at each point, and not on the whole product altogether again and again (Subramanian, 2015). The cost to the consumer will reduce, leading to increased consumption and production. Moreover, for it, one will ask for the documentation and returns to the firm one step lower on the value chain, leading to more compliance.

GST will lead to better monitoring and make it easier to administer commerce. It would also facilitate the shift of the informal economy to the formal economy. And formalization will help to bring the organized sector on the open field as that of small unorganized firms, although the government has made arrangements to protect the small firms as well by having composition scheme and threshold limits. Formalization which was basic objective for GST implementation is still not evident as per the report of HSBC as cited in (Press Trust of India, 2018). The report also states that in future, GST may formalize the economy and may also reduce demand for cash, which is still rising as Cash to GDP ratio is rising.

GST will impact the collection of direct taxes as well, due to greater compliance and improved detection technologies. As business transactions will increase, people doing them will have to show income out of it. This will reduce direct tax evasion (Srivats, 2017). A firm has to register as an ordinary taxpayer under
GST and file all returns, to sell online through the e-commerce portals. This has to be done irrespective of firm's turnover. Even the traders coming into the composition scheme are not allowed to sell goods through e-commerce portals without registration. This provision will keep the small unregistered businesses out of the e-commerce business. Pre GST, the tax liability was on the seller and not on e-commerce firm, but now the responsibilities have been passed on to the e-commerce operator. This means operation costs would move up for the e-commerce companies.

The Tax Collected at Source (TCS) mechanism will increase the record maintaining burden on the electronic commerce operators as now they will have to maintain the tax collection records and provide them to the government every month and undertake settlement (Shrivastav, 2017). TCS was implemented from October 1, 2018, through the $28^{\text {th }}$ GST Council meeting held on July 21, 2018 (GST Council, 2018).

As per the old system, e-commerce websites didn't have to collect the tax, whereas, under the GST, they will have to collect a tax of one per cent before paying to the sellers. This rule, however, does not apply to physical retailers, increasing the difficulties of online sellers. This is likely to make online shopping costlier (Gupta, 2017). Of the 1\%, SGST and CGST will have a $0.5 \%$ component each. Service tax has also been increased to $18 \%$ from $15 \%$, so services would become costlier (IANS, 2017). Textiles were never taxed but now has come into the preview of GST which can lead to increase in the prices of textiles and it was a significant component of fashion sales (Central Board of Excise and Custom, 2017).

The e-commerce operator has to report the product/ service code and the applicable rates for each item level individually. This requires them to map every sale done by the dealer and ensure TCS is deducted at the right value. The implementation of compliance is cumbersome for both e-commerce operator and the supplier. Additionally, the e-commerce operators will have to register in each state and file the reports separately on a monthly basis. This process increases the challenges in compliance and costs of running the business. In addition to that, all the countries had seen an initial inflation of 10-12 months when GST was introduced in their nations 
(PTI, 2017), hence increase in prices and slowdown in the e-commerce industry is also expected.

India is a very diverse nation not only culturally but also in the term of manufacturers; mixed of small-scale, medium-scale, and large-scale industries. This move had a negative impact on the unorganized, small and medium enterprise as they were unprepared and e-commerce companies major suppliers were those small firms only as large physical retailers can purchase in bulk from anywhere mainly from the large vendors (Pai, 2016). Most of the small manufactures or suppliers neither had the knowledge to use computers nor the resources to have one. Expenses of every small company would increase to have knowledge about the new system and to pay to the CAs. Small and medium enterprises which were hit majorly after demonetization will be again poorly hit as they may not be able to register or file returns. Flipkart and Amazon India made it compulsory for their suppliers to register on their sites with their new Goods and Services Tax Identification Numbers (GSTIN) (Ganguly, 2017). Lots of small suppliers have been dropped from e-commerce sites because they were unable to meet the new requirements (Rai, 2017). They didn't have a system or training and without registration or returns no one would purchase from them due to tax matching concept (Sharma, 2016) (Vasudevan, 2017) India's paradigm shift to the GST regime in July has increased the tax compliance costs and brought majority of the SME into the tax net for the first time. In addition to that, at every part of India internet is not available. But the council tried to do their bit in non-electronic modes it was smoothened where service providers with turnover less than 20 lakh don't have to file a return even when supplying interstate (GST Council, 2017). It can help the small-scale manufacturers and suppliers, not in an electronic medium.

Out of confusion about future speculations, manufacturers either stopped or reduced production of goods, so temporarily business output was quite low. There were pre-GST sales in all major platforms (Wankar, 2017). More to that, surprise element might have led to up-stocking or under-stocking which further resulted in artificial spikes or drop in demand in the assumption of increase or decrease in GST rate. In services, transitional problems would be there as earlier only center took care of it, but now the service providers will have to register with the state as well. The GST has some problems in its current form such as inputs are taxed at higher rates than final products, says outgoing NITI Aayog Vice-Chairman Arvind Panagariy (Bhattacharya, 2017). In addition to that around eight million registered businesses under the Value Added Tax (VAT) regime, around 90 per cent were Small and Medium Enterprises (SMEs). Only 10\% of the taxpayers under GST were prepared for it, leading to more transitional problems (Dey, 2017).

The Composition Scheme allows businesses with a turnover less than ₹ 75 lakhs initially (GST Council, 2017), which was later changed to $₹ 1$ crore in $22^{\text {nd }}$ meeting of GST Council on $6^{\text {th }}$ October 2017 and to ₹ 1.5 crores in $28^{\text {th }}$ GST Council meeting held on July 28, 2018 (28 ${ }^{\text {th }}$ GST Council, 2018). Further, they were instructed to file quarterly returns i.e., FORM GSTR4 , instead of monthly and to pay tax at as low rate as $1 \%$ (trading 1\%, Manufacturing 2\%, Restaurant $5 \%)$; making compliance easier and promotion of MSME. During the same $22^{\text {nd }}$ Council meeting, it was also decided that small and medium enterprises with turnover less than 1.5 crores will have to file quarterly returns. Facilities of composition scheme are not there in online selling, and all have to get registered in order to sell on online platform (Balasubramanyam \& Ganguly, 2017) which is very negative for e-commerce sellers. Additionally, the number of documents required to file a return is higher, lead to making the entire process more cumbersome and costly. In comparison, it had been smoothened in non-electronic mediums.

As per GST, all sellers supplying through an e-commerce operator need to do registrations under GST irrespective of their turnovers or value of supply they make. In this scenario, it becomes difficult for small businesses to keep a detailed record of purchases and sales and pay a higher rate of tax. Because of this, many small retailers may not prefer to work with an e-commerce company, which impacts the business of e-commerce operators. The government has specified a minimum turnover level of ₹ 20 lakh for getting mandatory registration under GST. However, for e-commerce operator, registration is mandatory, irrespective of their turnover. Removal of the threshold for registration will bring more online businesses into the sphere of taxation, increasing their difficulties. This condition 
is, however, applicable only if the supply is made through such e-commerce operator who is required to collect tax at source (TCS) under section 52 of the CGST Act, 2017. However, where the e-commerce operators are liable to pay tax on behalf of the suppliers under a notification issued under section 9 (5) of the CGST Act, 2017, the suppliers of such services are entitled to threshold exemption (CBEC, 2017). This is a point which online retailers can utilize to their favour.

Freebies were and still the most prominent attractions in any online sales. Under GST, even freebies are to be taxed creating an added burden on the sellers. Attracting an additional tax. An e-commerce operator will have to pay the tax on the charges it has paid for the purchase of the goods; it will not be worth its while to offer a discount in many cases, thus reducing the sales, discounts and offers online. Also, in case if an e-commerce operator decides to sell an item with discount, it will have to pay tax on the price it has given to the supplier for the purchase of the goods from that vendor, hence will have to bear the extra tax burden on its own (Balasubramanyam \& Ganguly, 2017).

Online retailers under GST will have to register in all the states and union territories, where it is selling online. Although e-retailers tried to convince the government to save them from the burden of registering separately in each of the states and union territories, under the GST regime (Balasubramanyam \& Ganguly, 2017) for which they got protection for a few months but they now have to get registered finally. E-commerce companies have a much higher return or cancellation rate of nearly $18 \%$, much more than in physical retail. Returns and cancellations will get difficult after the advent of GST and will be challenging for the online retail sector. In TCS format, e-commerce companies have to bear the tax amount of their own and later can get a refund from the government in case of any returns and cancellations, which generally happens in online sales. The companies will have to face significant cash-flow disadvantage due to order's returns and cancellations (Verma, 2017).

\section{CONCLUSION}

GST in its present form is quite complicated, and many items are still outside its ambit. With further amendments, it will become even more robust and efficient tax system which can also be supported by the fact that nearly 30 General GST Council meetings have been conducted till September 28, 2018. In short-term, there can be growth or decline in few sectors; in mid-term, more business will be done through the organized medium; and in longterm, the ease of doing business will improve with a decreased share of the unorganized businesses. The advent of GST would definitely promote organized business in the long run, however, it could also create a negative impact on the unorganized systems. Post-GST, government's move of extending the deadline for vendor matching was beneficial, especially for unorganized small and medium enterprises, otherwise, the sector would have struggled for existence. In relation to the online retail sector, the standardization that came along with GST has been welcomed but a feature of tax collection at source will dissuade sellers from cataloguing themselves and selling on e-commerce marketplaces which could hit the e-commerce industry badly. Compliance ratings given to each registered firm will have the most positive impact of GST on e-commerce as they have to rely on small suppliers which makes it difficult for inspections. A particular rating will surely help the operators in the selection of their respective vendors. GST is, of course, a complex and challenging system for a large section of the society, but it is still simpler than the older tax regime followed in India. Critics were right to a certain extent while stating that GST has its fair share of flaws, but since it is still in a nascent stage, the associated problems can be rectified only after its wider implementation. Few transitional problems are always there with such kind of a bold move. GST should not be judged in the short term as inflation was also observed in all others countries where similar taxation systems were implemented. Therefore, one should wait for its long-term results in order to arrive at a conclusion.

The probable negative implications of GST can be reduced by creating supporting infrastructure and mechanism to make it even more successful. Conducting workshops before implementation would have been better, but they can still be organized for enhancing the tax coverage. Small companies should form groups and hire experts to support them in the registration and return filing process, and within a quarter or two, they will 
get acquainted with the new system and in fact, may find it to be more user-friendly. Computer kiosks with experts to file returns at different industrial areas, especially where small and medium enterprises are concentrated, would be very helpful and would promote even more registrations and filing of returns. Making the GSTN website mobile friendly would solve many problems as the number of smartphone users is proliferating in India. The government is already making moves to protect the small manufacturers but should also consider helping the firms selling or supplying their products online by providing the benefits of composition scheme as well as benefits in registration in e-commerce. No separate registrations should be required in different states for online operators if the government wants to protect this industry which is still there at its nascent stage.

From the Indian perspective, the scholarly literature on the topic was quite scarce which forced the researchers to mainly rely on news articles and government reports. A primary research is suggested in future where data can be collected from manufacturers, suppliers, retailers, and consumers, which can be substantiated by secondary research on the same topic with data from different government organizations that can further strengthen the findings. Also, a future quantitative longitudinal study is suggested. The researchers further suggest a comparative analysis of India with other nations in which GST has already been implemented in the past so as to find the suggestions for better implementation with reduced negative impacts and increased positive impacts. Additionally, the effect of GST on other variables like foreign exchange rate, stock prices, FDI/FII inflows GDP growth rate, Indexed of Industrial Production (IIP), unemployment rate, consumer and wholesale price index can also be studied in future.

\section{REFERENCES}

$23^{\text {rd }}$ GST Council Meeting, 2017. Decisions relating to Services in $23^{\text {rd }}$ GST Council meeting at Guwahati, Guwahati: s.n. $28^{\text {th }}$ GST Council, 2018. PRESS NOTE on GST rate on Services. [Online] Available at: http://www.gstcouncil.gov.in/sites/default/ files/Services-21072107.pdf

Agarwal, A., 2017. Money Today: GST: Changing the face of Indian businesses. [Online] Available at: http://www. businesstoday.in/opinion/columns/money-today/gst- changing-the-face-of-indian-businesses/story/247490. html [Accessed 10 September 2017].

ANI, 2017. GST to help create national market, improve tax compliance: Chanda Kochhar. [Online] Available at: http:// www.business-standard.com/article/economy-policy/gstto-help-create-national-market-improve-tax-compliancechanda-kochhar-17063000606_ 1.html [Accessed 12 September 2017].

Arora, K. et al. 2017. GST of IT. s.l.: The Hindu.

Balasubramanyam, K. \& Ganguly, P., 2017. GST may bring bad news for small e-commerce retailers. [Online] Available at: http://retail.economictimes.indiatimes.com/ news/e-commerce/e-tailing/gst-may-bring-bad-newsfor-small-e-commerce-retailers/58971375 [Accessed 16 August 2017].

Bhattacharya, A. 2017. Govt may revisit GST in 2-3 years and unify many rates: Arvind Panagariya. [Online] Available at: http://www.business-standard.com/article/economypolicy/govt-may-revisit-gst-in-2-3-years-and-unifymany-rates-arvind-panagariya-117080900393_1.html [Accessed 13 November 2017].

Biswas, S. 2016. Why India's GST is one of the world's most complex tax reforms. [Online] Available at: http:// www.bbc.com/news/world-asia-india-36950205 [Accessed 20 August 2017].

Business Standard, 2017. Getting SMEs ready for GST. [Online] Available at: http://www.rediff.com/money/report/gstgetting-smes-ready-for-gst/20170327.htm [Accessed 12 September 2017].

CBEC Goods and Service Tax, 2017. The Goods and Services Tax (Compensation to States) Act. [Online] Available at: https://cbec-gst.gov.in/compensation-cess-bill-e.html [Accessed 15 September 2017].

CBEC, 2017. GST Sectoral Series E-commerce, New Delhi: s.n.

Central Board of Excise \& Customs, 2017. Integrated Goods and Service Tax, s.l.: Central Board of Excise \& Customs.

Central Board of Excise and Custom, 2017. GST Rates. [Online] Available at: https://cbecgst.gov.in/gst-goods-services-rates.html [Accessed 10 September 2017].

Cleartax, 2018 . 29th GST Council Meeting - Key Highlights $\mathcal{E}$ Decisions. [Online] Available at: https://cleartax.in/s/29thgst-council-meet-news

Cnossen, S., 2013. Preparing the way for a modern GST in India. International Tax and Public Finance, 20(4): 715-723.

Creswell, J.W. \& Poth, C.N. 2017. Qualitative inquiry and research design: Choosing among five approaches.. s.l.:Sage publications..

Dash, N. 2017. GST: 100 FAQs received by Modi regime on Twitter. [Online] Available at: http://indiatoday.intoday. in/story/gst-faqs-received-by-pm-modi-regime-ontwitter/1/988477.html [Accessed 8 September 2017].

Dey, S. 2017. Getting SMEs ready for GST. [Online] Available at: http://www.business-standard.com/article/ opinion/getting-smes-ready-for-gst-117031900732_1.html [Accessed 11 September 2017]. 
Economic Times, 2017. A quick guide to India GST rates in 2017. [Online] Available at: http://economictimes.indiatimes. com/news/economy/policy/a-quick-guide-to-india-gstrates-in-2017/articleshow/58743715.cms [Accessed 12 September 2017].

ET Retail, 2017. Impact of GST on e-commerce marketplace: Here is all you need to know. [Online] Available at: https://retail. economictimes.indiatimes.com/news/industry/impact-ofgst-on-e-commerce-marketplace-here-is-all-you-need-toknow/57428592

Ganguly, P., 2017. GST impact on e-commerce: Marketplaces put an embargo on non-compliant merchants. [Online] Available at: https://economictimes.indiatimes.com/ industry/services/retail/gst-impact-on-e-commercemarketplaces-put-an-embargo-on-non-compliantmerchants/articleshow/59431750.cms

GoI, 2015. Report on the Revenue Neutral Rate and, New Delhi: GST Council.

GOI, 2015. Report on the Revenue Neutral Rate and Structure of Rates for the Goods and Services Tax (GST) - December 4, 2015, New Delhi: GST Council.

Goods and Service tax Council, 2018. On GST rate on goods as recommended by the GST council in its 28th meeting held on 21.07.2018.. [Online] Available at: http://www.gstcouncil. gov.in/sites/default/files/goods-21-07-18.pdf

GST Council, 2016. Model GST LAW, New Delhi: GST Council Secretariat.

GST Council, 2017. Goods and Service Tax Council. [Online] Available at: http://www.gstcouncil.gov.in/gst-council [Accessed 14 September 2017].

GST Council, 2017. Recommendations made by the GST Council in the 22nd meeting at New Delhi on 6th, s.l.: GOI.

GST Council, 2018. GST-An Update, Delhi: s.n.

GSTGOVT, 2017. What is considered as e-commerce according to GST rules?. [Online] Available at: http://www.gstgovt. in/what-is-considered-as-e-commerce-according-to-gstrules/

Gupta, A., 2017. How GST will change your online shopping experience from July 1. [Online] Available at: https:// economictimes.indiatimes.com/news/economy/ policy/how-gst-will-change-your-online-shoppingexperience-from-july-1/articleshow/59319112.cms [Accessed 13 November 2017].

IANS, 2017. GST rollout: 50,000 Delhi cloth shops on threeday strike seeking exemption. [Online] Available at: http://www.business-standard.com/article/economypolicy/gst-rollout-50-000-delhi-cloth-shops-on-threeday-strike-seeking-exemption-117062700900_1.html [Accessed 20 August 2017].

IANS, 2017. Service tax may move up from $15 \%$ to $18 \%$ under GST: Revenue Secretary Hasmukh Adhia. [Online] Available at: http://economictimes. indiatimes.com/news/economy/finance/service-taxmay-move-up-from-15-to-18-under-gst-revenuesecretary-hasmukh-adhia/articleshow/58161886.cms [Accessed 7 September 2017].
IBEF, 2017. Retail Industry in India. [Online] Available at: https://www.ibef.org/industry/retail-india.aspx [Accessed 5 September 2017].

Indian Express Web Desk, 2017. Full list of items for which GST has been reduced. [Online] Available at: http:// indianexpress.com/article/business/economy/full-list-ofitems-for-which-gst-has-been-reduced-4878520/

Kashyap, K. 2017. The Four Benefits Of The New Goods And Services Tax (GST) For Startups In India. [Online] Available at: https://www.forbes.com/sites/krnkashyap/2017/07/10/ the-four-benefits-of-the-new-goods-and-servicestax-gst-for-startups-in-india/2/\#66c350b84e88 [Accessed 10 September 2017].

Madhav, P., 2017. Tamil Nadu: 1100 theatres to go on strike from tomorrow against GST. [Online] Available at: http:// indiatoday.intoday.in/story/tamil-nadu-theatres-strikegst-entertainment-movie-ticket/1/992602.html [Accessed 5 September 2017].

Nair, R., 2017. GSTN preparing to handle 3 billion invoices a month: Prakash Kumar. [Online] Available at: http://www.livemint.com/Politics/ TGOQEievh8xUEIo8oBXpEN/GSTN-preparing-tohandle-3-billion-invoices-a-month-Prakash.html [Accessed 10 August 2017].

Pai, G., 2016. Not only demonetisation, GST to also hit unorganised players: Girish Pai, Nirmal Bang. [Online] Available at: http:// economictimes.indiatimes.com/markets/expert-view/ not-only-demonetisation-gst-to-also-hit-unorganisedplayers-girish-pai-nirmal-bang/articleshow/55564439.cms [Accessed 30 August 2017].

Press Trust of India, 2015. Cloth merchants in Ahmedabad go on indefinite strike against GST. [Online] Available at: http://timesofindia.indiatimes.com/business/indiabusiness/cloth-merchants-on-indefinite-strike-fromtomorrow-against-gst/articleshow/59517231.cms [Accessed 12 August 2017].

Press Trust of India, 2017. GST Council approves law for compensating states' revenue loss. [Online] Available at: http://indianexpress.com/article/business/economy/gstcouncil-approves-law-for-compensating-states-revenueloss-4531991/[Accessed 2017].

Press Trust of India, 2017. TDS, TCS Deductors Can Apply For GST Registration From September 18. [Online] Available at: https://www.bloombergquint.com/gst/2017/09/10/ tds-tcs-deductors-can-apply-for-gst-registration-fromseptember-18 [Accessed 14 September 2017].

Press Trust of India, 2018. GST fails its biggest promiseformalisation of economy: HSBC report. [Online] Available at: https://www.business-standard.com/article/economypolicy/gst-fails-its-biggest-promise-formalisationof-economy-says-hsbc-report-118062200695_1.html [Accessed 25 October 2018].

Press Trust of India, 2018. Now, only 35 goods in highest tax bracket of GST. [Online] Available at: https:// timesofindia.indiatimes.com/business/india-business/ now-only-35-goods-in-highest-tax-bracket-of-gst/ articleshow/65090713.cms 
PTI, 2016. US welcomes passage of GST bill, says will improve investment partnership. [Online] Available at: http://indianexpress.com/article/business/economy/ us-welcomes-passage-of-gst-bill-says-will-improveinvestment-partnership-2963128/

PTI, 2017. Centre, states taxmen to decide services rate in GST this week. [Online] Available at: http://www.livemint. com/Politics/f1BVFcZ6Uit0HVqQxmA8EL/Centre-statestaxmen-to-decide-services-rate-in-GST-this-we.html [Accessed 10 September 2017].

PTI, 2017. GST rollout from 1 July will have serious problems: West Bengal FM Amit Mitra. [Online] Available at: http:// www.livemint.com/Politics/ivaYu1FkRv6K1Kkz5WvEoO/ GST-rollout-from-1-July-will-have-serious-problemsWest-Ben.html [Accessed 12 September 2017].

Rai, S., 2017. GST brings pain, paperwork to India's online sellers. [Online] Available at: http://www.livemint.com/ Industry/qaWbySrq4RgjtIpiw1sOvK/GST-brings-painpaperwork-to-Indias-online-sellers.html [Accessed 12 November 2017].

Rastogi, A., 2017. Unease over GST'S anti-profiteering clauses. [Online] Available at: http://www.thehindubusinessline. com/opinion/unease-over-gsts-antiprofiteering-clauses/ article9740440.ece [Accessed 14 September 2017].

Saurav, S., 2018. One Year Of GST: The Hits Definitely Outnumber The Misses. [Online] Available at: https://www. outlookindia.com/website/story/one-year-of-gst-the-hitsdefinitely-outnumber-the-misses/312981 [Accessed 27 September 2018].

Seth, D., 2017. We're very, very stressed; working 28 hours a day: GSTN chief Navin Kumar. [Online] Available at: http:// www.business-standard.com/article/economy-policy/ no-time-for-software-testing-now-gstn-chairman-navinkumar-117062600040_1.html [Accessed 5 September 2017].

Seth, D., 2018. E-way bill may be relaxed for e-commerce players if orders are small. [Online] Available at: https://www. business-standard.com/article/economy-policy/e-waybill-may-be-relaxed-for-e-commerce-players-if-ordersare-small-118022500539_1.html

Sharma, S., 2016. GST to hit consumers, unorganised jobs most. [Online] Available at: http://www.tribuneindia.com/ news/nation/gst-to-hit-consumers-unorganised-jobsmost/275659.html [Accessed 8 September 2017].

Shivashankar, B., 2017. GST ratings will help you know how genuine your trader is. [Online] Available at: http:// timesofindia.indiatimes.com/city/bengaluru/gst-ratingswill-help-you-know-how-genuine-your-trader-is/ articleshow/59480014.cms [Accessed 10 September 2017].
Shrivastav, A., 2017. Selling online. [Online] Available at: http:// www.thehindubusinessline.com/opinion/gst-masterclassby-ajay-srivastav/article9737568.ece [Accessed 15 September 2017].

Singh, S., 2017. A look at how GST was rolled out in other countries. [Online] Available at: http://economictimes.indiatimes. com/news/economy/policy/a-look-at-how-gst-wasrolled-out-in-other-countries/articleshow/59359815.cms [Accessed 10 September 2017].

Srivats, K. 2017. GST will impact direct taxes too: Jaitley. [Online] Available at: http://www.thehindubusinessline.com/ economy/gst-impact-will-be-seen-on-direct-taxes-toojaitley/article9836844.ece [Accessed 13 November 2017].

Subramanian, A., 2015. In principle, prices shouldn't rise after GST [Interview] (11 December 2015).

Subramanian, A. 2017. Chief Eco Adviser, GOI addresses on GST during Orientation Prog for Delhi MLA's. [Interview] (29 May 2017).

Tharoor, S. 2017. GST Bill 2017 in LIk Sabha [Interview] (2 Ausgust 2017).

Thirteenth Finance Commission, 2009. Report of the task force on goods $\mathcal{E}$ services tax, s.l.: s.n.

TOI, 2017. 'Manmohan Singh's 1991 budget was biggest reform country has seen. GST deals with just one indirect tax'. [Online] Available at: https://blogs.timesofindia.indiatimes.com/ the-interviews-blog/manmohan-singhs-1991-budget-wasbiggest-reform-country-has-seen-gst-deals-with-just-oneaspect-taxation/[Accessed 11 September 2017].

TOI, 2017. GST guide: What destination-based-tax means?. [Online] Available at: https://timesofindia.indiatimes. $\mathrm{com} /$ business/faqs/gst-faqs/gst-guide-what-destinationbased-tax-means/articleshow/60192046.cms [Accessed 13 November 2017].

Vasudevan, R. 2017. How will GST impact MSMEs?. [Online] Available at: http://www.thehindubusinessline.com/ opinion/how-will-gst-impact-msmes/article9702208.ece [Accessed 5 September 2017].

Verma, S., 2017. GST law poses multiple challenges for e-commerce firms. [Online] Available at: http://www.livemint.com/ Companies/i45nwN0FnKEfABtFEc7I1I/GST-law-posesmultiple-challenges-for-ecommerce-firms.html [Accessed 13 November 2017].

Wankar, G. 2017. Big discounts on ACs, cars, phones to beat GST deadline. [Online] Available at: http://www. hindustantimes.com/business-news/discounts-galore-asretailers-brands-try-to-clear-stock-ahead-of-gst-rollout/ story-HXSj8Uyw2N8TrtBB0rFt7M.html [Accessed 12 September 2017]. 
